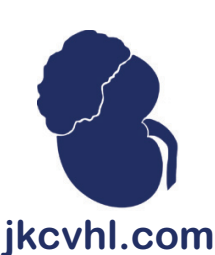

ORIGINAL ARTICLE

\title{
Predictors of Cytoreductive Nephrectomy for Metastatic Kidney Cancer in SEER and Metropolitan Detroit Databases
}

\author{
Ulka Vaishampayan, Julie George, Fawn Vigneau \\ Department of Oncology, Karmanos Cancer Center, Wayne State University, Detroit, MI, USA
}

\begin{abstract}
Patients without cytoreductive nephrectomy $(\mathrm{CN})$ are inadequately represented in metastatic renal cell carcinoma (RCC) clinical trials. The characteristics that impact the decision of $\mathrm{CN}$ were explored in the SEER database. Data on primary, regional, or distant (metastatic) stage kidney cancer over the period 2000-2013 were extracted from the National Cancer Institute Surveillance, Epidemiology, and End Results Program (SEER-18) database. A sub-analysis of Metropolitan Detroit cases, to evaluate the influence of comorbidities, was conducted. Logistic regression was used to calculate the odds ratios, and Cox model was used to calculate hazard ratios; $37 \%$ of 21,052 metastatic RCC cases had CN performed. $\mathrm{CN}$ demonstrated significant survival advantage (HR $=0.31,95 \%$ confidence interval [CI]: $0.30-0.33$ ). Comorbidity data were available on $76 \%$ of distant RCC cases from the Detroit SEER database. Neither hypertension, diabetes mellitus nor the number of comorbidities $(0,1$ or 2$)$ had a statistically significant impact on the likelihood of CN. Majority of patients $(63 \%)$ with distant-stage RCC do not undergo CN and have a median overall survival (OS) of 3 months as compared to a median OS of 18 months for patients who have undergone CN. Patient demographics and tumor characteristics make a significant impact on the incidence of $\mathrm{CN}$. The impact of comorbidities (number and type) was modest and not statistically significant. The optimal management of patients with synchronous primary and metastatic RCC needs to be prospectively evaluated in the setting of contemporary systemic therapy.
\end{abstract}

Keywords: comorbidities; kidney cancer; nephrectomy; prognostic factors; SEER registry

Received: 02 August 2019; Accepted after revision: 02 October 2019; Published: 28 October 2019

Author for Correspondence: Ulka Vaishampayan, MD, 4100 John R, Detroit, MI 48201, USA. Email: vaishamu@karmanos.org

How to cite: Vaishampayan et al. Predictors of cytoreductive nephrectomy for metastatic kidney cancer in SEER and metropolitan Detroit databases. J Kidney Cancer VHL 2019;6(1): 13-25.

Doi: http://dx.doi.org/10.15586/jkcvhl.2019.121

Copyright: Vaishampayan et al.

License: This open access article is licensed under Creative Commons Attribution 4.0 International (CC BY 4.0). http://creativecommons.org/ licenses/by/4.0

\section{Introduction}

Cytoreductive nephrectomy $(\mathrm{CN})$ in the presence of metastatic disease is a unique feature of the therapeutics of advanced renal cancer (RCC). There are two randomized trials demonstrating the overall survival (OS) benefit favoring $\mathrm{CN}$ in metastatic disease compared to systemic interferon therapy alone $(1,2)$. The only systemic therapies available previously were cytokine-based regimens such as interleukin and interferon during the time period when these $\mathrm{CN}$ trials were conducted. Within the last decade, 10 additional therapies have attained Food and Drug Administration (FDA) approval in metastatic renal cancer (3). Until recently, no prospective study had been completed evaluating the role of 
$\mathrm{CN}$ in the setting of contemporary systemic therapies. The results of two randomized trials comparing $\mathrm{CN}$ followed by sunitinib versus systemic therapy with sunitinib followed by CN [SURTIME trial] and nephrectomy followed by sunitinib versus sunitinib alone (CARMENA) were recently reported. Both studies indicated that the clinical outcomes with sunitinib alone were at least similar and possibly slightly improved in the metastatic RCC patients randomized to deferred or no $\mathrm{CN}(4,5)$. The studies showed that $\mathrm{CN}$ does not impart additional survival benefit in the setting of effective systemic therapy, and a proportion of patients are deprived of systemic therapy due to complications of CN. In summary, the concept of $\mathrm{CN}$ being an essential component of metastatic RCC therapy is being seriously questioned. These data need to be considered in future therapeutic decisions in metastatic RCC.

The National Cancer Database (NCDB), which reflects community-based data from hospitals with Commission on Cancer accreditation, continues to reveal that the incidence of $\mathrm{CN}$ in distant-/advanced-stage RCC is seen in about a third of the patients (6). Unlike clinical trials of systemic therapy, where $80-100 \%$ of patients are receiving nephrectomy, the majority of the patients in the real-world treatment of RCC are not receiving $\mathrm{CN}$ as primary management. The overall survival outcome has improved in advanced RCC; however, it also appears that the patients with $\mathrm{CN}$ received the maximum benefit (7). Despite randomized evidence to the contrary, the OS results in SEER show that $\mathrm{CN}$ patients have a large magnitude of benefit as compared to non-CN patients. This finding may be confounded by the fact that the patients undergoing $\mathrm{CN}$ are probably younger, healthier, and less likely to have aggressive or poor risk disease, factors that portend an improved prognosis regardless of nephrectomy status. In an attempt to overcome the confounding effect of conflicting prognostic factors, we analyzed and reported on a clinical trial population with metastatic disease and found that $\mathrm{CN}$ maintained a significant positive impact on clinical outcomes (8).

In the targeted therapy era, we conducted a SEER data analysis of outcomes in patients who have undergone $\mathrm{CN}$ versus those who have not undergone $\mathrm{CN}$. The results revealed that only the post-nephrectomy population appeared to benefit from advances in systemic therapies (8). Clearly, an intervention that would increase the possibility of $\mathrm{CN}$ in metastatic RCC would likely improve outcomes. The controversy of whether $\mathrm{CN}$ should be standard in metastatic RCC continues, with the recent randomized prospective trials suggesting minimal contribution of $\mathrm{CN}$ in improving outcomes in metastatic RCC. In addition, there is an added nuance of analyzing the role of $\mathrm{CN}$ in the presence of contemporary immune checkpoint combination therapy. There is preclinical evidence that suggests that the immune checkpoint inhibitors would be primed to demonstrate improved efficacy in the presence of the primary tumor. Randomized trials of systemic therapy with immune checkpoint inhibition with or without $\mathrm{CN}$ are being planned in this setting.

We attempted to evaluate the magnitude of the problem by assessing the incidence of $\mathrm{CN}$ in metastatic RCC within the SEER data. We analyzed the factors that are likely to impact the decision of $\mathrm{CN}$ in the initial management of advanced RCC. We explored demographic and disease-related factors. In addition, we assessed the impact of comorbidities in receipt of initial $\mathrm{CN}$ using additional data from the Metropolitan Detroit Cancer Surveillance System (MDCSS). We conducted an analysis of distant/metastatic cases of RCC within the SEER-18 data between 2000 and 2013. The intention was to evaluate the incidence of $\mathrm{CN}$ in the contemporary systemic therapy era and to assess the factors that impacted the decision of $\mathrm{CN}$. We chose to explore the impact of a few key comorbidities such as renal function, hypertension, diabetes mellitus, and lung disease.

\section{Methods}

The National Cancer Institute Surveillance, Epidemiology, and End Results Program (SEER-18) contains regional research data (1973-2011) submitted in November 2013 with the Katrina/Rita population adjustment, collected from 18 American cancer registries, chosen for their data quality and population diversity. The MDCSS is a data contributor to the SEER Program. Data for the primary analyses were extracted using SEER*Stat software (version 8.3.1), for patients diagnosed with renal cancer between the years 2000 and 2013. We restricted the analysis to the first diagnosis of regional or distant stage kidney cancer, overall referred to as "metastatic" kidney cancer. Site-specific surgery codes $30,40,50,70$, or 80 were defined as having received nephrectomy. The main focus was advanced or metastatic cases with RCC which are coded as "distant" in SEER. Logistic regression analysis was used to calculate odds ratios (OR) of a patient who has undergone nephrectomy, adjusted for age at diagnosis, race, gender, marital status, insurance and disease histology, and grade. Cox proportional hazards regression analysis was used to calculate adjusted hazard ratios (HR) to estimate the overall risk of death. Hazard ratios were adjusted for nephrectomy as well as for all other variables listed above. Analyses were conducted using SAS software version 9.4 (SAS Institute Inc., Cary, NC). Patients with OS $<1$ month were excluded from the analysis with the assumption that any treatment would not have a chance to impact their outcomes. Figure 1 depicts the flowchart of the patient population considered and selected for analysis.

We also performed a separate analysis using the same criteria for MDCSS data, extracted from the local SEER Database Management System (SEER*DMS) using SASC v 9.4, to evaluate the influence of comorbidities, as these data are not collected by SEER. Logistic regression was used to 


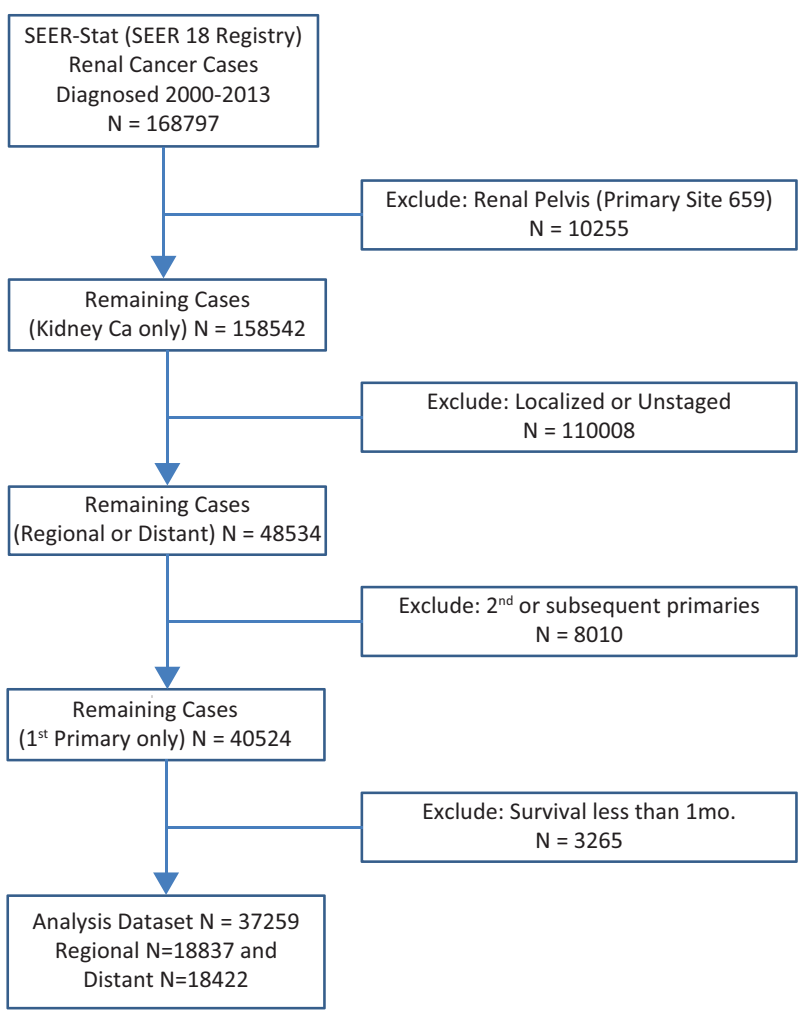

Figure 1: Consort diagram of patient population included in analyses.

calculate the odds ratios for receiving $\mathrm{CN}$. Hazard ratios were calculated using Cox proportional hazards regression.

\section{Results}

\section{Overview and predictors of nephrectomy}

After exclusion of renal pelvis cases, final SEER-18 data for 2000-2013 had $\mathrm{N}=40,524$ patients. Case distribution by stage included regional stage $(\mathrm{N}=19,472,48 \%, 93 \%$ had nephrectomy) and distant stage ( $\mathrm{N}=21,052,52 \%, 37 \%$ had nephrectomy). Our analyses were restricted to distant or metastatic stage patients only (Figure 1). The population characteristics of all SEER registry "regional" and "distant cases" are depicted in Table 1.

Adjusted predictors of statistically increased likelihood of receiving nephrectomy were age ( $\leq 63$ years), male sex (white race), and marital status. An interaction effect was noted between gender and marital status with married males having a significantly higher nephrectomy rate $(42 \%)$ than divorced, single, and widowed men $(35,38$, and $18 \%$ respectively). Single males were significantly less likely to receive nephrectomy than females (OR $0.53,95 \%$ confidence interval [CI] 0.44-0.64). Single females had the highest (44\%) likelihood of nephrectomy. Non-clear cell histology and poorly differentiated grade had a higher possibility of receiving $\mathrm{CN}$ as compared to clear cell histology and well-differentiated cancer, respectively (Table 2).

\section{Survival status}

Receipt of nephrectomy demonstrated significant survival advantage $(\mathrm{HR}=0.31,95 \% \mathrm{CI}: 0.30-0.33)$ in the adjusted hazards ratio model. Median OS was 3 months in the non- $\mathrm{CN}$ group and 18 months in the $\mathrm{CN}$ group (Table 3 and Figure 2A). The demographic predictors of improved survival were age $<63$, white race, married status, and insured status (Table 3). Clear cell histology $(\mathrm{HR}=1.20,95 \% \mathrm{CI}: 1.16-1.24)$ and well-differentiated grade are the disease-related characteristics that portend for improved OS (Figure 2B). The latter demonstrated improved OS despite a lower, $43 \% \mathrm{CN}$ rate as compared to $84 \%$ in the undifferentiated histology group. The histology grades in SEER of well, moderate, poor, and undifferentiated RCC are likely to be concordant with the conventional Fuhrman 1-4 grading (Table 3).

\section{Comorbidity analyses in Metro Detroit Registry}

The data regarding comorbid conditions were only available for the Metro Detroit (MDCSS) Registry. While not collected as a population-based variable, comorbidity status was coded for $82 \%$ of regional and $76 \%$ of metastatic kidney cancers seen in Metropolitan Detroit. Nephrectomy was performed in $92 \%$ of regional stage and $34 \%$ of distant stage patients; our analysis pertains to only the distant-stage patients. Dichotomous comorbidities (yes or no for: hypertension, cardiac disease, diabetes mellitus, kidney disease, and lung disease) and number of comorbid conditions (none, 1, 2, 3+, and missing) are included in the patient characteristics of MDSCC (Table 4). The demographic and tumor characteristics were concordant with the all SEER data; $44.9 \%$ of the patients had none of the comorbidities. Adjusted demographic predictors of increased likelihood of receiving nephrectomy for Metropolitan Detroit patients were age $<64$ years, non-black race, and married status. Non-clear cell histology $(\mathrm{OR}=$ 2.16, 95\% CI: 1.42-3.28) and undifferentiated or high also predicted a higher likelihood of CN. Adding comorbidities and number of comorbidities to the model did not impact the likelihood of receiving nephrectomy. All comorbidity types and numbers were not statistically significant in terms of predicting the likelihood of $\mathrm{CN}$ and OS (Table 5). Patients with hypertension (OR $=1.75,95 \%$ CI: $0.63-4.87)$ or diabetes mellitus had greater likelihood of receiving nephrectomy $(\mathrm{OR}=1.16,95 \% \mathrm{CI}: 0.42,3.21)$. The group of patients with missing comorbidity data $(261 / 1104,23.6 \%)$ had a significantly shorter OS in both $\mathrm{CN}$ and non-CN categories. The actual correlation of comorbidities with likelihood of $\mathrm{CN}$ remains elusive due to the group with missing data constituting $24 \%$ of the population; $26 \%$ of this group had a 
Table 1: Population Characteristics and Nephrectomy Rates of All SEER Kidney Cancer, Regional or Distant Stage: $2000-2013$.

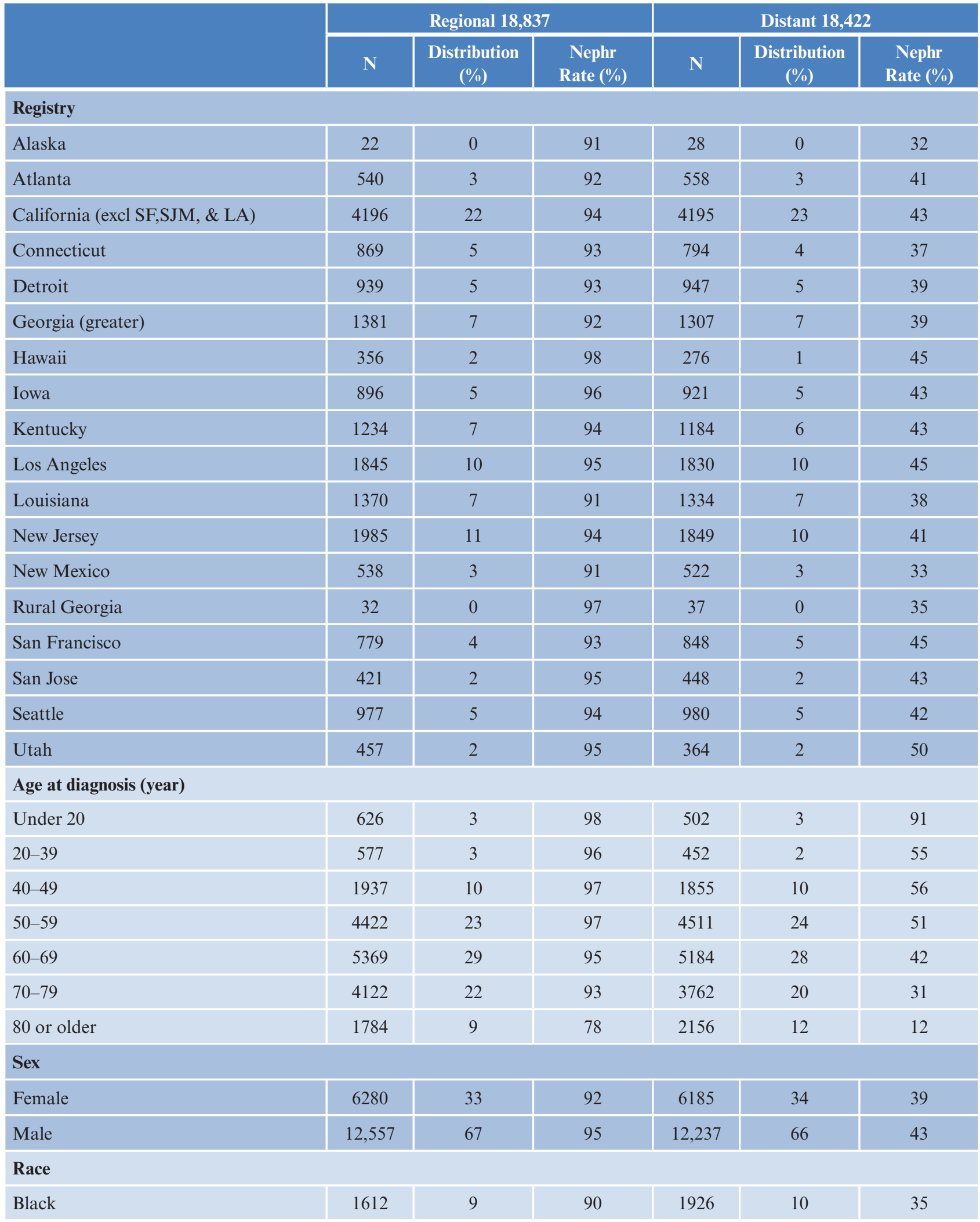


Table 1 (Continued): Population Characteristics and Nephrectomy Rates of All SEER Kidney Cancer, Regional or Distant Stage: 2000-2013.

\begin{tabular}{|c|c|c|c|c|c|c|}
\hline & \multicolumn{3}{|c|}{ Regional 18,837 } & \multicolumn{3}{|c|}{ Distant 18,422} \\
\hline & $\mathbf{N}$ & $\begin{array}{c}\text { Distribution } \\
(\%)\end{array}$ & $\begin{array}{c}\text { Nephr } \\
\text { Rate }(\%)\end{array}$ & $\mathbf{N}$ & $\begin{array}{c}\text { Distribution } \\
(\%)\end{array}$ & $\begin{array}{c}\text { Nephr } \\
\text { Rate (\%) }\end{array}$ \\
\hline White & 16,020 & 85 & 94 & 15,241 & 83 & 42 \\
\hline Other & 1102 & 6 & 96 & 1208 & 7 & 44 \\
\hline Unknown & 103 & 1 & 98 & 47 & 0 & 40 \\
\hline \multicolumn{7}{|l|}{ Marital status } \\
\hline Married & 11,556 & 61 & 96 & 10,482 & 57 & 46 \\
\hline Divorced & 1700 & 9 & 92 & 1994 & 11 & 39 \\
\hline Single & 2959 & 16 & 95 & 3077 & 17 & 45 \\
\hline Widowed & 1890 & 10 & 85 & 2230 & 12 & 22 \\
\hline Unknown & 732 & 4 & 85 & 639 & 3 & 33 \\
\hline \multicolumn{7}{|l|}{ Insurance } \\
\hline Insured & 8449 & 45 & 95 & 7573 & 41 & 43 \\
\hline Uninsured/medicaid & 1530 & 8 & 93 & 1887 & 10 & 36 \\
\hline Unknown/missing & 8858 & 47 & 93 & 8962 & 49 & 41 \\
\hline \multicolumn{7}{|l|}{ Histology } \\
\hline Clear cell & 14,287 & 76 & 94 & 13,952 & 76 & 39 \\
\hline Renal cell carcinoma, Chromophobe & 662 & 4 & 98 & 125 & 1 & 76 \\
\hline Renal cell carcinoma, Sarcomatoid & 488 & 3 & 95 & 878 & 5 & 62 \\
\hline Collecting duct carcinoma & 90 & 0 & 94 & 98 & 1 & 67 \\
\hline Papillary carcinoma, Oxyphilic cell & 0 & 0 & - & 1 & 0 & 100 \\
\hline Other non-clear cell & 3310 & 18 & 93 & 3368 & 18 & 46 \\
\hline \multicolumn{7}{|l|}{ Grade } \\
\hline Well differentiated & 859 & 5 & 97 & 318 & 2 & 45 \\
\hline Moderately differentiated & 5513 & 29 & 99 & 1750 & 9 & 71 \\
\hline Poorly differentiated & 5902 & 31 & 98 & 3653 & 20 & 73 \\
\hline Undifferentiated & 2319 & 12 & 98 & 2233 & 12 & 86 \\
\hline Unknown & 4244 & 23 & 78 & 10,468 & 57 & 16 \\
\hline \multicolumn{7}{|l|}{ Surgery } \\
\hline Nephrectomy & 17,665 & 94 & & 7660 & 42 & \\
\hline Other surgery & 142 & 1 & & 179 & 1 & \\
\hline No urgery & 1016 & 5 & & 10,500 & 57 & \\
\hline Unknown if Surgery done & 14 & 0 & & 83 & 0 & \\
\hline
\end{tabular}

Nephr Rate, nephrectomy rate. 
Table 2: All SEER Distant Stage Kidney Cancer: 2000-2013; Odd Ratios for Likelihood of Nephrectomy.

\begin{tabular}{|c|c|c|c|c|c|c|}
\hline Total & N 18422 & $\begin{array}{c}\text { Nephr. Rate } \\
42(\%)\end{array}$ & $\begin{array}{c}\text { Unadjusted } \\
\text { OR }\end{array}$ & $\begin{array}{c}\text { Adjusted } \\
\text { OR }\end{array}$ & $95 \% \mathrm{CI}$ & p-value \\
\hline \multicolumn{7}{|c|}{ Age at Diagnosis Diagnosis (median 63) } \\
\hline (ref) Under 63 & 8982 & 53 & 1.00 & 1.00 & & \\
\hline 63 or Older & 9440 & 31 & 0.39 & 0.41 & $(0.38-0.44)$ & $<0.001$ \\
\hline \multicolumn{7}{|l|}{ Race (47 missing) } \\
\hline (ref) Black & 1926 & 35 & 1.00 & 1.00 & & \\
\hline White & 15241 & 42 & 1.34 & 1.51 & $(1.33-1.72)$ & $<0.001$ \\
\hline Other & 1208 & 44 & 1.43 & 1.52 & $(1.25-1.84)$ & $<0.001$ \\
\hline Unknown & 47 & 40 & & N/A & & \\
\hline \multicolumn{7}{|l|}{ Insurance } \\
\hline (ref) Insured & 7573 & 43 & 1.00 & 1.00 & & \\
\hline Medicaid or Uninsured & 1887 & 36 & 0.75 & 0.65 & $(0.57-0.75)$ & $<0.001$ \\
\hline Unknown or Missing & 8962 & 41 & 0.93 & 1.17 & $(1.08-1.27)$ & $<0.001$ \\
\hline \multicolumn{7}{|l|}{ Histology } \\
\hline (ref) Clear Cell & 13952 & 39 & 1.00 & 1.00 & & \\
\hline Non-Clear Cell & 4470 & 50 & 1.59 & 1.58 & $(1.45-1.73)$ & $<0.001$ \\
\hline \multicolumn{7}{|l|}{ Grade } \\
\hline (ref) Well differentiated & 318 & 45 & 1.00 & 1.00 & & \\
\hline Moderately differentiated & 1750 & 71 & 3.06 & 3.35 & $(2.59-4.33)$ & $<0001$ \\
\hline Poorly differentiated & 3653 & 73 & 3.32 & 3.24 & $(2.53-4.13)$ & $<0001$ \\
\hline Undifferentiated & 2233 & 86 & 7.54 & 7.15 & $(5.49-9.31)$ & $<0001$ \\
\hline Unknown & 10468 & 16 & 0.24 & 0.23 & $(0.18-0.29)$ & $<0001$ \\
\hline \multicolumn{7}{|l|}{ Sex } \\
\hline (ref) Female & 6185 & 39 & 1.00 & \multirow{2}{*}{\multicolumn{3}{|c|}{ See interaction below }} \\
\hline Male & 12237 & 43 & 1.16 & & & \\
\hline \multicolumn{7}{|l|}{ Marital Status } \\
\hline (ref) Married & 10482 & 46 & 1.00 & \multirow{5}{*}{\multicolumn{3}{|c|}{ See interaction below }} \\
\hline Divorced & 1994 & 39 & 0.75 & & & \\
\hline Single & 3077 & 45 & 0.96 & & & \\
\hline Widowed & 2230 & 22 & 0.34 & & & \\
\hline Unknown & 639 & 33 & 0.58 & & & \\
\hline \multicolumn{7}{|l|}{ Sex by Marital Status } \\
\hline \multicolumn{7}{|l|}{ Married } \\
\hline (ref) Female & 2715 & 46 & 1.00 & 1.00 & & \\
\hline
\end{tabular}


Table 2 (Continued): All SEER Distant Stage Kidney Cancer: 2000-2013; Odd Ratios for Likelihood of Nephrectomy.

\begin{tabular}{|c|c|c|c|c|c|c|}
\hline Total & N 18422 & $\begin{array}{c}\text { Nephr. Rate } \\
42(\%)\end{array}$ & $\begin{array}{c}\text { Unadjusted } \\
\text { OR }\end{array}$ & $\begin{array}{c}\text { Adjusted } \\
\text { OR }\end{array}$ & $95 \%$ CI & p-value \\
\hline Male & 7767 & 46 & 1.00 & 1.03 & $(0.92-1.16)$ & 0.567 \\
\hline \multicolumn{7}{|l|}{ Divorced } \\
\hline (ref) Female & 742 & 40 & 1.00 & 1.00 & & \\
\hline Male & 1252 & 38 & 0.93 & 0.79 & $(0.62-1.00)$ & 0.047 \\
\hline \multicolumn{7}{|l|}{ Single } \\
\hline (ref) Female & 984 & 49 & 1.00 & 1.00 & & \\
\hline Male & 2093 & 43 & 0.76 & 0.53 & $(0.44-0.64)$ & $<0.001$ \\
\hline \multicolumn{7}{|l|}{ Widowed } \\
\hline (ref) Female & 1528 & 22 & 1.00 & 1.00 & & \\
\hline Male & 702 & 23 & 1.03 & 1.03 & $(0.79-1.34)$ & 0.963 \\
\hline \multicolumn{7}{|l|}{ Unknown } \\
\hline (ref) Female & 216 & 28 & 1.00 & 1.00 & & \\
\hline Male & 423 & 35 & 1.43 & 1.33 & $(0.84-2.09)$ & 0.298 \\
\hline
\end{tabular}

Italic values represent missing data.

nephrectomy and demonstrated a median OS of 8 months as compared to the $76 \%$ with a median OS of 2 months (Tables 4 and 5; Figure $3 \mathrm{~A}$ and $3 \mathrm{~B}$ ).

\section{Discussion}

Our analysis reveals that $\mathrm{CN}$ is not being conducted in the majority of patients that present with synchronous metastatic RCC. There is a tremendous discordance between the population of advanced RCC enrolled in prospective interventional clinical trials in which $80-90 \%$ of the patients have had nephrectomy, and the application of these reported efficacy data to clinical practice in which the majority of patients do not undergo $\mathrm{CN}$. There is a discrepancy between the results of retrospective population-based data such as the SEER cancer registry outcomes data and the IMDC registry data in which $\mathrm{OS}$ is significantly better with $\mathrm{CN}$, and those seen in prospective randomized trial results such as the CARMENA and SURTIME studies that show that $\mathrm{CN}$ is unlikely to make an impact on improving outcomes in the setting of contemporary anti-VEGF therapy such as sunitinib (9). SEER data consistently demonstrate that lack of $\mathrm{CN}$ is the largest contributor of shorter OS in RCC patients with distant-stage RCC. The factors included within the IMDC are not captured within the SEER database, and hence, comparison of patients within these different registries is not possible. However, it is highly likely that the extent of the impact of each factor on OS may not be equal, and interaction between the factors is likely. In addition, it is possible that synchronous presentation of primary kidney tumor and metastases represents a distinct disease entity than the presentation with metastatic disease following a remote history of nephrectomy (>12 months) for localized renal cancer.

The advent of immune therapy with checkpoint inhibitors has introduced a new perspective to the sequencing of $\mathrm{CN}$ and systemic therapy in metastatic RCC. Preclinical data continue to emerge supporting the optimal use of immune checkpoint inhibition with the primary tumor in place, due to higher mutation load, increased heterogeneity of mutations and greater potential for anti-tumor CD8 T cells expansion and cytokine release $(10,11)$. These findings demand a deeper evaluation of the established paradigm of initial $\mathrm{CN}$ in metastatic RCC followed by systemic therapy. In fact, this standard is already being questioned in localized RCC by the current cooperative group trial EA8143/PROSPER, which randomizes patients to standard therapy of $\mathrm{CN}$ or neoadjuvant PD-1 inhibitor therapy with nivolumab followed by $\mathrm{CN}$. In the metastatic disease also, deferral of nephrectomy as a potential method of enhancing the efficacy of immune checkpoint inhibition needs to be prospectively evaluated. SEER-18 limited use data do not include systemic agents, and this was a limitation of our analysis. A Southwest Oncology Group trial, S1931, is proposing to evaluate immune checkpoint inhibitor-based regimen combination with or without the addition of $\mathrm{CN}$. The timing of surgery in the nephrectomy arm will be at the end of 12 weeks of immune therapy to optimize the impact of systemic therapy. The study design is that of a randomized phase III with overall survival as the primary endpoint. 
Table 3: All SEER Distant Stage Kidney Cancer (2000-2013) Survival Analysis (Median Survival, Adjusted Hazard Ratio, 95\% Confidence Interval, and P-value).

\begin{tabular}{|c|c|c|c|c|c|c|}
\hline \multirow[b]{2}{*}{ Total } & \multirow{2}{*}{$\begin{array}{c}\mathrm{N} \\
18422\end{array}$} & \multicolumn{2}{|c|}{ Median Survival (months) } & \multirow[b]{2}{*}{ HR } & \multirow[b]{2}{*}{$95 \% \mathrm{CI}$} & \multirow[b]{2}{*}{ p-value } \\
\hline & & $\begin{array}{c}\text { Nephr. } \\
18\end{array}$ & $\begin{array}{c}\text { No Nephr. } \\
5\end{array}$ & & & \\
\hline \multicolumn{7}{|c|}{ Age at Diagnosis (median 63) } \\
\hline (ref) Under 63 & 8982 & 20 & 25 & 1.00 & & \\
\hline 63 or Older & 9440 & 16 & 4 & 1.16 & $(1.12-1.20)$ & $<0.001$ \\
\hline \multicolumn{7}{|l|}{ Sex } \\
\hline (ref) Female & 6185 & 18 & 4 & 1.00 & & \\
\hline Male & 12237 & 19 & 5 & 0.99 & $(0.96-1.03)$ & 0.702 \\
\hline \multicolumn{7}{|l|}{ Race (47 missing) } \\
\hline (ref) Black & 1926 & 16 & 4 & 1.00 & & \\
\hline White & 15241 & 25 & 5 & 0.98 & $(0.93-1.02)$ & 0.342 \\
\hline Other & 1208 & 18 & 5 & 0.88 & $(0.81-0.95)$ & 0.002 \\
\hline \multicolumn{7}{|l|}{ Marital Status } \\
\hline (ref) Married & 10482 & 17 & 5 & 1.00 & & \\
\hline Divorced & 1994 & 16 & 5 & 1.05 & $(1.00-1.11)$ & 0.051 \\
\hline Single & 3077 & 29 & 5 & 0.86 & $(0.82-0.90)$ & $<0.001$ \\
\hline Widowed & 2230 & 14 & 4 & 1.09 & $(1.04-1.15)$ & 0.001 \\
\hline Unknown & 639 & 20 & 5 & 0.86 & $(0.79-0.94)$ & 0.001 \\
\hline \multicolumn{7}{|l|}{ Insurance } \\
\hline (ref) Insured & 7573 & 20 & 5 & 1.00 & & \\
\hline Medicaid or Uninsured & 1887 & 21 & 5 & 1.03 & $(0.97-1.09)$ & 0.427 \\
\hline Unknown or Missing & 8962 & 16 & 4 & 1.16 & $(1.12-1.20)$ & 0.001 \\
\hline \multicolumn{7}{|l|}{ Histology } \\
\hline (ref) Clear Cell & 13952 & 20 & 5 & 1.00 & & \\
\hline Non-Clear Cell & 4470 & 13 & 4 & 1.16 & $(1.12-1.21)$ & $<0.001$ \\
\hline \multicolumn{7}{|l|}{ Grade } \\
\hline (ref) Well differentiated & 318 & 35 & 9 & 1.00 & & \\
\hline Moderately differentiated & 1750 & 30 & 6 & 1.30 & $(1.13-1.49)$ & $<0.001$ \\
\hline Poorly differentiated & 3653 & 18 & 4 & 1.86 & $(1.63-2.13)$ & $<0.001$ \\
\hline Undifferentiated & 2233 & 11 & 3 & 2.47 & $(2.16-2.83)$ & $<0.001$ \\
\hline Unknown & 10468 & 26 & 5 & 1.48 & $(1.30-1.69)$ & $<0.001$ \\
\hline \multicolumn{7}{|l|}{ Surgery } \\
\hline No Nephrectomy & 10762 & - & 5 & 1.00 & & \\
\hline Nephrectomy & 7660 & 18 & - & 0.34 & $(0.32-0.35)$ & $<0.001$ \\
\hline
\end{tabular}



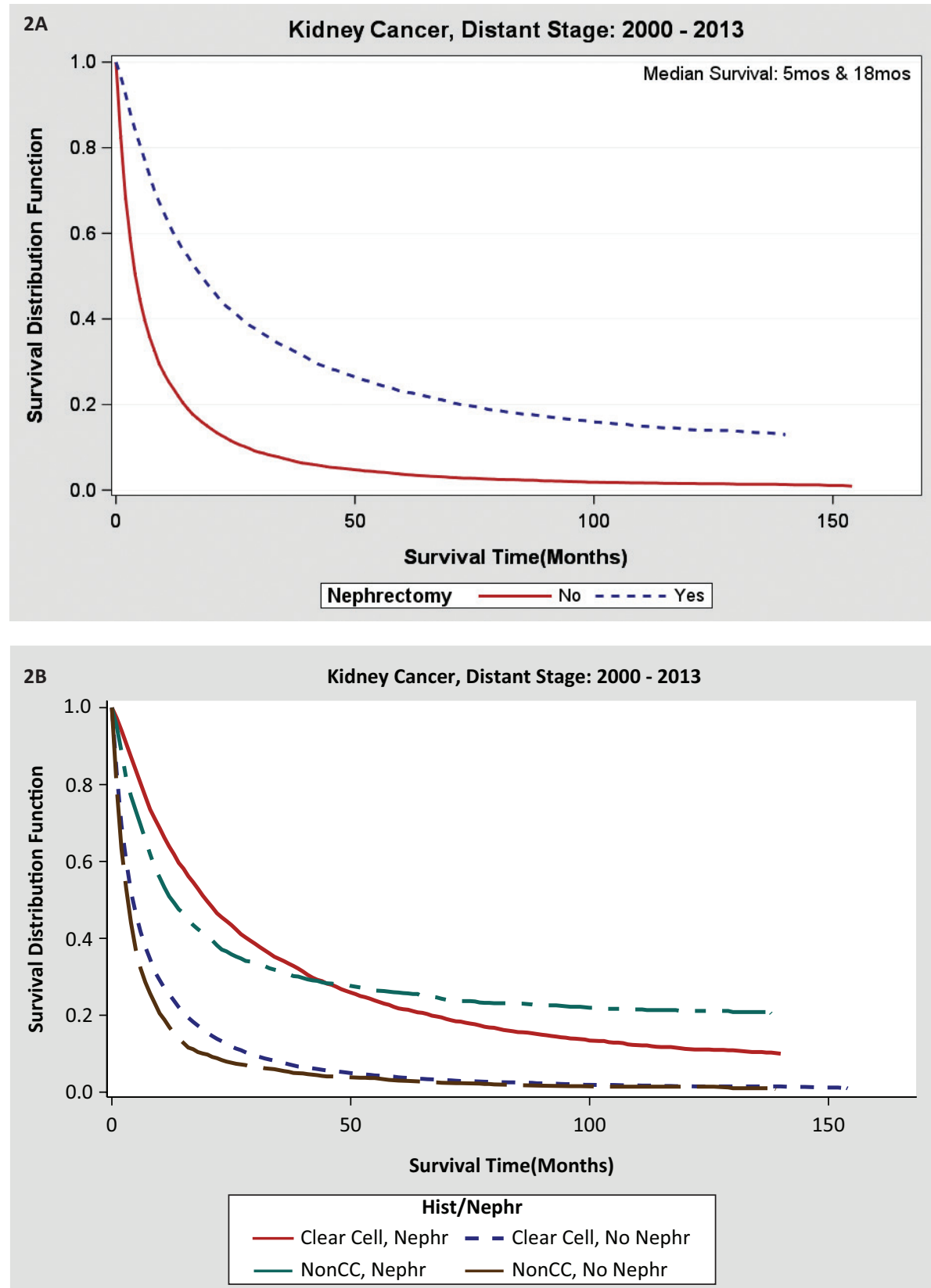

Figure 2: (A) Overall survival data for nephrectomy or non-nephrectomy patients with advanced kidney cancer in SEER database. (B) Overall survival outcomes in metastatic RCC by clear and non-clear histology with or without nephrectomy.

\section{Conclusions}

National population registry represented by the SEER database shows that the majority of patients $(63 \%)$ with metastatic RCC do not undergo CN. Nephrectomy still represents a significant factor that predicts for improved OS outcome in advanced RCC within population databases such as SEER and NCDB. Median OS of 3 months in the non-CN group and that of 18 months for cases with
$\mathrm{CN}$ suggests the large magnitude of the disparity. Patient demographics and tumor characteristics make a significant impact on the incidence of $\mathrm{CN}$. The impact of comorbidities (number and type) appeared to be modest within the population represented in the Metropolitan Detroit SEER data and was not statistically significant. The optimal management strategy of patients with advanced RCC unable to undergo nephrectomy needs to be prospectively 
Table 4: Metropolitan Detroit Distant Stage Kidney Cancer: 2000-2013 Odd Ratios for Likelihood of Nephrectomy.

\begin{tabular}{|c|c|c|c|c|c|c|}
\hline Total & N 1008 & Distribution & $\begin{array}{c}\text { Nephr. Rate } \\
37(\%)\end{array}$ & Adjusted OR & $95 \%$ CI & $p$-value \\
\hline \multicolumn{7}{|c|}{ Age at Diagnosis (median 64) } \\
\hline (ref) Under 64 & 498 & 49 & 51 & 1.00 & & \\
\hline 64 or Older & 510 & 51 & 23 & 0.29 & $(0.21-0.39)$ & $<0.001$ \\
\hline \multicolumn{7}{|l|}{ Sex } \\
\hline (ref) Female & 338 & 34 & 36 & 1.00 & & \\
\hline Male & 670 & 66 & 37 & 0.87 & $(0.64-1.19)$ & 0.389 \\
\hline \multicolumn{7}{|l|}{ Race } \\
\hline (ref) Black & 206 & 20 & 34 & 1.00 & & \\
\hline White & 788 & 78 & 38 & 1.48 & $(1.03-2.13)$ & 0.035 \\
\hline Other & 14 & 1 & 36 & - & & \\
\hline \multicolumn{7}{|l|}{ Marital Status } \\
\hline (ref) Married & 507 & 50 & 40 & 1.00 & & \\
\hline Divorced & 118 & 12 & 31 & 0.60 & $(0.38-0.95)$ & 0.031 \\
\hline Single & 202 & 20 & 43 & 0.81 & $(0.56-1.19)$ & 0.285 \\
\hline Widowed & 146 & 14 & 21 & 0.51 & $(0.31-0.83)$ & 0.006 \\
\hline Unknown & 35 & 3 & 37 & 1.13 & $(0.52-2.44)$ & 0.757 \\
\hline \multicolumn{7}{|l|}{ Insurance } \\
\hline (ref) Insured & 663 & 66 & 38 & 1.00 & & \\
\hline Medicaid or Uninsured & 277 & 27 & 40 & 1.12 & $(0.79-1.59)$ & 0.524 \\
\hline Unknown or Missing & 67 & 7 & 18 & 0.41 & $(0.21-0.81)$ & 0.010 \\
\hline
\end{tabular}

\section{Histology}

\begin{tabular}{|c|c|c|c|c|c|c|}
\hline (ref) Clear Cell & 695 & 69 & 34 & 1.00 & & \\
\hline Non-Clear Cell & 313 & 31 & 45 & 1.68 & $(1.25-2.27)$ & 0.001 \\
\hline \multicolumn{7}{|l|}{ Grade } \\
\hline (ref) Well or Mod Diff & 75 & 7 & 44 & \multirow{4}{*}{\multicolumn{3}{|c|}{$\begin{array}{l}\text { left out of model because of the } \\
\text { large proportion of unknowns }\end{array}$}} \\
\hline Poorly Diff & 168 & 17 & 70 & & & \\
\hline Undifferentiated & 152 & 15 & 81 & & & \\
\hline Unknown & 613 & 61 & 16 & & & \\
\hline \multicolumn{7}{|c|}{ Number of Comorbid conditions } \\
\hline (ref) None of the above & 465 & 46 & 36 & 1.00 & & \\
\hline One & 165 & 16 & 41 & 1.25 & $(0.84-1.87)$ & 0.269 \\
\hline Two or more & 156 & 15 & 46 & 1.76 & $(1.17-2.66)$ & 0.007 \\
\hline Missing data & 222 & 22 & 31 & 0.80 & $(0.54-1.18)$ & 0.249 \\
\hline
\end{tabular}

95\% CI, 95\% confidence interval; Mod Diff, moderately differentiated. 
Table 5: Metropolitan Detroit Distant Stage Kidney Cancer: 2000-2013 Survival Analysis by Nephrectomy Status for Demographic Characteristics and Comorbidities.

\begin{tabular}{|c|c|c|c|c|c|c|}
\hline \multirow{2}{*}{ Total } & \multirow{2}{*}{$\begin{array}{c}\mathbf{N} \\
1008\end{array}$} & \multicolumn{2}{|c|}{ Median Survival (months) } & \multirow[b]{2}{*}{ HR } & \multirow[b]{2}{*}{$95 \%$ CI } & \multirow[b]{2}{*}{ p-value } \\
\hline & & $\begin{array}{c}\text { Nephr. } \\
19\end{array}$ & $\begin{array}{c}\text { No Nephr. } \\
5\end{array}$ & & & \\
\hline \multicolumn{7}{|c|}{ Age at Diagnosis (median 64) } \\
\hline (ref) Under 64 & 551 & 22 & 5 & 1.00 & & \\
\hline 64 or Older & 553 & 15 & 5 & 1.08 & $(0.93-1.25)$ & 0.335 \\
\hline \multicolumn{7}{|l|}{ Sex } \\
\hline (ref) Female & 370 & 19 & & 1.00 & & \\
\hline Male & 734 & 20 & & 1.00 & $(0.86-1.16)$ & 0.990 \\
\hline \multicolumn{7}{|l|}{ Race (55 missing) } \\
\hline (ref) Black & 232 & 30 & 4 & 1.00 & & \\
\hline White & 857 & 18 & 5 & 1.02 & $(0.86-1.21)$ & 0.824 \\
\hline Other & 15 & - & - & - & & \\
\hline \multicolumn{7}{|l|}{ Marital Status } \\
\hline (ref) Married & 552 & 18 & 5 & 1.00 & & \\
\hline Divorced & 122 & 12 & 4 & 1.18 & $(0.95-1.46)$ & 0.145 \\
\hline Single & 222 & 43 & 4 & 0.76 & $(0.62-0.93)$ & 0.007 \\
\hline Widowed & 169 & 17 & 4 & 1.02 & $(0.82-1.25)$ & 0.891 \\
\hline Unknown & 39 & 16 & 8 & 0.71 & $(0.49-1.02)$ & 0.064 \\
\hline \multicolumn{7}{|l|}{ Insurance } \\
\hline (ref) Insured & 720 & 18 & 5 & 1.00 & & \\
\hline Medicaid or Uninsured & 309 & 22 & 4 & 1.02 & $(0.86-1.22)$ & 0.784 \\
\hline Unknown or Missing & 75 & 31 & 4 & 1.35 & $(1.03-1.78)$ & 0.032 \\
\hline \multicolumn{7}{|l|}{ Histology } \\
\hline (ref) Clear Cell & 755 & 20 & 5 & 1.00 & & \\
\hline Non-Clear Cell & 349 & 18.5 & 4 & 1.17 & $(1.01-1.36)$ & 0.037 \\
\hline \multicolumn{7}{|l|}{ Grade } \\
\hline (ref) Well or Mod Diff & 76 & 35 & 9 & \multirow{4}{*}{\multicolumn{3}{|c|}{$\begin{array}{l}\text { left out of model because of the large } \\
\text { proportion of unknowns }\end{array}$}} \\
\hline Poorly Diff & 178 & 19 & 4 & & & \\
\hline Undifferentiated & 158 & 12 & 3 & & & \\
\hline Unknown & 692 & 36 & 5 & & & \\
\hline \multicolumn{7}{|l|}{ Surgery } \\
\hline No Nephrectomy & 726 & - & 3 & 1.00 & & \\
\hline Nephrectomy & 378 & 19 & - & 0.40 & $(0.34-0.46)$ & $<0.001$ \\
\hline
\end{tabular}


Table 5 (Continued): Metropolitan Detroit Distant Stage Kidney Cancer: 2000-2013 Survival Analysis by Nephrectomy Status for Demographic Characteristics and Comorbidities.

\begin{tabular}{|c|c|c|c|c|c|c|}
\hline \multirow[b]{2}{*}{ Total } & \multirow{2}{*}{$\begin{array}{c}\mathbf{N} \\
1008\end{array}$} & \multicolumn{2}{|c|}{ Median Survival (months) } & \multirow[b]{2}{*}{ HR } & \multirow[b]{2}{*}{$95 \%$ CI } & \multirow[b]{2}{*}{ p-value } \\
\hline & & $\begin{array}{c}\text { Nephr. } \\
19\end{array}$ & $\begin{array}{c}\text { No Nephr. } \\
5\end{array}$ & & & \\
\hline \multicolumn{7}{|c|}{ Number of Comorbid conditions } \\
\hline (ref) None of the above & 496 & 24 & 5 & 1.00 & & \\
\hline One & 178 & 24 & 4 & 1.12 & $(0.92-1.36)$ & 0.275 \\
\hline Two or more & 169 & 18 & 5 & 1.10 & $(0.90-1.35)$ & 0.370 \\
\hline Missing data & 261 & 8.5 & 4 & 1.68 & $(1.39-2.01)$ & $<0.001$ \\
\hline
\end{tabular}

95\% CI, 95\% confidence interval; Mod Diff, moderately differentiated; Nephr, nephrectomy.
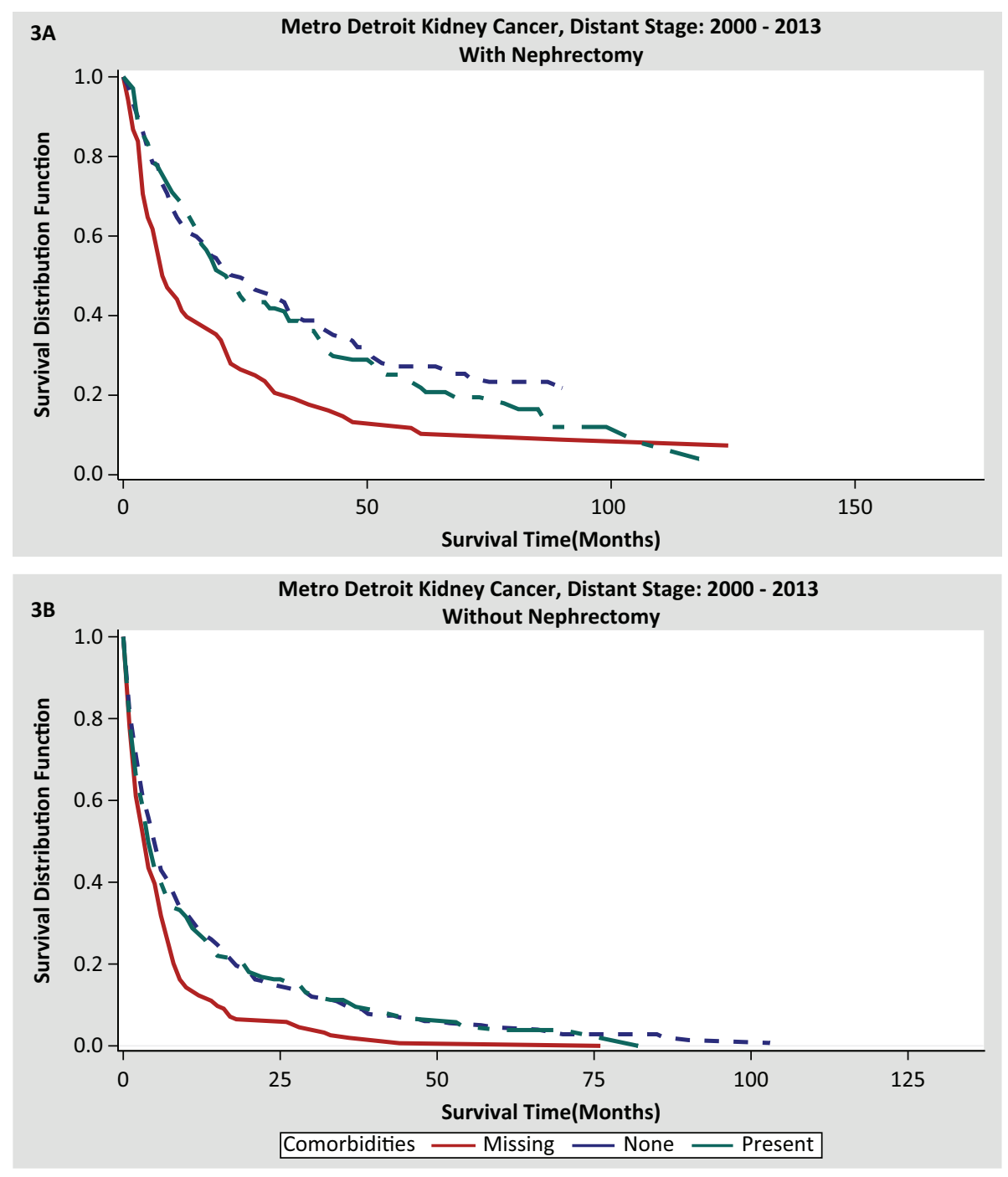

Figure 3: (A) Overall survival noted in cases with nephrectomy correlated with missing, absence, and presence of comorbidities. (B) Overall survival seen in cases with no nephrectomy correlated with missing, absence, and presence of comorbidities. 
evaluated in future clinical trials, in the setting of contemporary systemic therapy.

The subgroup of synchronous primary and metastatic kidney cancer has been underrepresented in clinical trials. Future studies geared toward addressing the issues of optimal efficacy of therapy within this patient population are being planned. Patient and disease characteristics that determine decision of $\mathrm{CN}$ warrant further study and may represent a key to the enhancement of outcomes in advanced renal cancer.

\section{Conflict of Interest}

The authors declare that they have no conflict of interest.

\section{References}

1. Flanigan RC, Salmon SE, Blumenstein BA, Bearman SI, Roy V, McGrath PC, et al. Nephrectomy followed by interferon al$\mathrm{fa}-2 \mathrm{~b}$ compared with interferon alfa- $2 \mathrm{~b}$ alone for metastatic renal-cell cancer. N Engl J Med. 2001;345:1655-9. http://dx.doi. org/10.1056/NEJMoa003013

2. Mickisch G, Garin A, Van Poppel H, de Prijck L, Sylvester R. Radical nephrectomy plus interferon-alfa-based immunotherapy compared with interferon alfa alone in metastatic renal-cell carcinoma: A randomised trial. Lancet. 2001;358:966-70. http:// dx.doi.org/10.1016/S0140-6736(01)06103-7

3. Graham J, Heng DYC, Brugarolas J, Vaishampayan U. Personalized management of advanced kidney cancer. Am Soc Clin Oncol Educ Book. 2018 May 23;(38):330-41. http://dx.doi. org/10.1200/EDBK_201215
4. Bex A, Mulders P, Jewett M, Wagstaff, J, van Thienen JV, Blank CU, et al. Comparison of immediate vs deferred cytoreductive nephrectomy in patients with synchronous metastatic renal cell carcinoma receiving sunitinib: The SURTIME Randomized Clinical Trial. JAMA Oncol. 2019 Feb 1;5(2):164-70. http://dx.doi.org/10.1001/jamaoncol.2018.5543

5. Méjean A, Ravaud A, Thezenas S, Colas S, Beauval JB, Bensalah K, et al. Sunitinib alone or after nephrectomy in metastatic renal-cell carcinoma. N Engl J Med. 2018;379(5):417-27. http://dx.doi.org/10.1056/NEJMoa1803675

6. Hanna N, Sun M, Meyer CP, Nguyen PL, Pal SK, Chang $\mathrm{SL}$, et al. Survival analyses of patients with metastatic renal cancer treated with targeted therapy with or without cytoreductive nephrectomy: A National Cancer Data Base Study. J Clin Oncol. 2016;34(27):3267-75. http://dx.doi.org/10.1200/ JCO.2016.66.7931

7. Vaishampayan U, Vankayala H, Vigneau FD, Quarshie W, Dickow B, Chalasani S, et al. The effect of targeted therapy on overall survival in advanced renal cancer: A study of the national surveillance epidemiology and end results registry database. Clin Genitourin Cancer. 2014 Apr;12(2):124-9. http:// dx.doi.org/10.1016/j.clgc.2013.09.007

8. Tripathi RT, Heilbrun LK, Jain V, Vaishampayan UN. Racial disparity in outcomes of a clinical trial population with metastatic renal cell carcinoma. Urology. 2006 Aug;68(2):296-301. http://dx.doi.org/10.1016/j.urology.2006.02.036

9. Heng DY, Wells JC, Rini BI, Beuselinck B, Lee JL, Knox JJ, et al. Cytoreductive nephrectomy in patients with synchronous metastases from renal cell carcinoma: Results from the International Metastatic Renal Cell Carcinoma Database Consortium. Eur Urol. 2014 Oct;66(4):704-10.

10. Harshman LC, Drake CG, Choueiri TK. PD-1 blockade in renal cell carcinoma: To equilibrium and beyond. Cancer Immunol Res. 2014 Dec;2(12):1132-41. http://dx.doi.org/10.1158/23266066.CIR-14-0193 